ENTREPRENEURSHIP AND SUSTAINABILITY ISSUES

ISSN 2345-0282 (online) http://jssidoi.org/jesi/

2020 Volume 7 Number 3 (March)

http://doi.org/10.9770/jesi.2020.7.3(8)

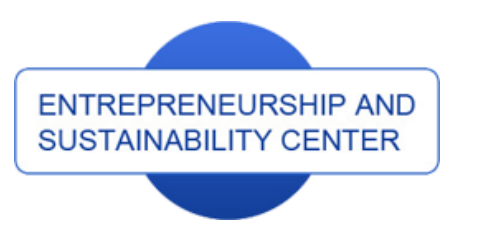

Publisher

http://jssidoi.org/esc/home

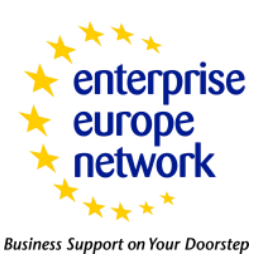

CASPA

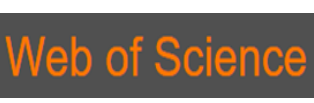

I Clarivate

Analytics

\title{
SUSTAINABLE ECONOMY: EVALUATION OF FOOD SELF-SUFFICIENCY IN RUSSIA*
}

\author{
Veronika Yu. Chernova ${ }^{1}$, Alexander M. Zobov ${ }^{2}$, Ekaterina A. Degtereva ${ }^{3}$, Vasily S. Starostin ${ }^{4}$, \\ Inna V. Andronova 5 \\ 1,2,3,5 Peoples' Friendship University of Russia, 6, Miklukho-Maklaya Str., Moscow, 117198, Russian Federation \\ 1,4 State University of Management, 99, Ryazanskiy prospect st., Moscow, 109542, Russian Federation
}

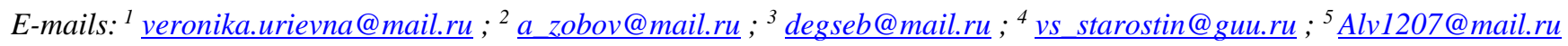

Received 15 August 2019; accepted 20 December 2019; published 30 March 2020

\begin{abstract}
The level of food self-sufficiency is a relevant aspect of food security. The paper studies food self-sufficiency in the context of economic and physical availability of food. It develops an approach to assessing the level of food self-sufficiency which includes a number of indicators, such as international trade, food consumption standards and diversification of food imports. Empirical testing of the approach is performed within the agricultural sector of Russia for 2012-2018, where import substitution policy is being actively implemented. The research results demonstrate that in Russia only three food groups are self-sufficient, whereas all other categories are characterized by extremely low self-sufficiency levels. Having compared the self-sufficiency levels, the authors discover a discrepancy between the assessment method applied by the Russian Federal State Statistics Service (Rosstat) and that proposed in the paper; the difference between the two methods can reach up to $40 \%$. The study indicates that there is a decrease in diversification of imports, which poses the risk of undersupply of foodstuffs. The research finds that the domestic production of grains exceeds the rational consumption norms, which results in the excessive consumption of this type of food, if compared to the recommended standards. At the same time, self-sufficiency in dairy products and vegetables is low and self-sufficiency in fruits is extremely low. The article concludes that Russia's Food Security Doctrine is focused on production, but not consumer, which necessitates its assessment indicators to be revised.
\end{abstract}

Keywords: food self-sufficiency; food; food security; diversification of import; food availability; rational consumption norms

Reference to this paper should be made as follows: Chernova, V. Yu., Zobov, A.M., Degtereva, E.A., Starostin, V.S. Andronova, I.V. 2020. Sustainable economy: evaluation of food self-sufficiency in Russia. Entrepreneurship and Sustainability Issues, 7(3), 1541-1554. https://doi.org/10.9770/jesi.2020.7.3(8)

JEL Classifications: Q18, Q11, F13

\footnotetext{
* The reported study was funded by RFBR (Russian Foundation for Basic Research), "Intensification of military-economic cooperation in the space of the Collective Security Treaty Organization and the Eurasian Economic Union in the context of the sanctions policy of developed countries and the development of import substitution in the Russian Federation”, project № 18-010-01132.
} 


\section{ENTREPRENEURSHIP AND SUSTAINABILITY ISSUES}

ISSN 2345-0282 (online) http://jssidoi.org/jesi/

2020 Volume 7 Number 3 (March)

http://doi.org/10.9770/jesi.2020.7.3(8)

\section{Introduction}

Agro-industrial policy of all countries is premised on the concept of food security. The original approaches to food security concentrated on stockpiling (Report of the World Food Conference, 1974), which indicates the physical availability of food. Later, insufficient purchasing power of a part of population became a threat to food security, which caused the parameter of economic availability to be included in the food security evaluation. Nowadays, the issues of health, the amount of nutrients in food and the quality of foods are widely debated (Ecker \& Breisinger, 2012). The three aspects - physical/economic availability, safety and quality of food - as well as their stability over time, appear in the most commonly used definitions of food security (FAO, 2001).

A high level of self-sufficiency is a prerequisite for food security. The issues of self-sufficiency have gained in popularity after the global financial crisis of 2007-2008. A range of countries, such as India, Qatar, Philippines, Senegal, Bolivia, etc. shifted their policies towards enhancing food self-sufficiency. This provoked considerable discussions among scientists (Clapp, 2017; Moumen et al., 2019). The supporters of the food self-sufficiency policy argue that every country has the right to protect itself from crises in global food markets by increasing domestic food production. According to the opponents of the food self-sufficiency policy, reducing imports and increasing domestic production are more of a political goal than an economic one. Growing self-sufficiency in foods will result not only in an increase in the foodstuffs cost of the country that pursues that policy (due to the absence or shortage of natural or other resources for production (Todorov et al., 2018)), but will also have disastrous consequences for the whole world (Financial Times, 2009).

In this context, there are two main types of decisions in the field of agro-industrial policy aimed at ensuring food security, namely domestic production and import. The situation where a country is fully self-sufficient in domestic products and, therefore, does not participate in world food trade is extremely rare, and represents more of a theoretical abstraction. All countries, including large food exporters, to a certain extent rely on import, at least for some food groups. Participation in the international division of labor provides plenty of opportunities to resolve food problems in the most efficient manner. At the same time, increased protectionism in the agri-food sector inevitably leads to a rise in prices. The measures causing food prices to grow decrease their affordability for population, and this undermines food security of a country (Zagashvili, 2015).

Import substitution policy implemented in some countries including Russia is a prototype of the autarchy mechanism, the purpose of which is to limit food imports while concentrating on domestic food production. The assessments of the effectiveness of import substitution policy are ambiguous. Therefore, we look at the concept of food self-sufficiency from the perspective of system-based and balanced approaches. On this basis, we propose a method for evaluating food self-sufficiency and prove that, despite the import substitution policy actively enforced in Russia over the last few years, not all food categories are self-sufficient.

\section{Literature Review}

The problems associated with sufficiency and availability of food in various countries are addressed in burgeoning literature on the topic. Many researchers emphasize that, despite growing production volumes and food supplies, the problem of ensuring food security is relevant for all countries (Baer-Nawrocka \& Sadowski, 2019). In literature, food security is mostly interpreted as independence and ability to maintain self-sufficiency exclusively by producing domestic food amid full or partial isolation (Zagashvili, 2015).

According to the Food and Agriculture Organization (FAO, 1999), food self-sufficiency is defined as the extent to which a country can satisfy its food needs from its own domestic production. The situation, where food production is equal to food consumption, corresponds to $100 \%$ self-sufficiency. In other words, self-sufficiency in food suggests that a country produces as much food as is sufficient to fully satisfy its population's needs. The 


\section{ENTREPRENEURSHIP AND SUSTAINABILITY ISSUES}

ISSN 2345-0282 (online) http://jssidoi.org/jesi/

2020 Volume 7 Number 3 (March)

http://doi.org/10.9770/jesi.2020.7.3(8)

given definition leaves open the question of the country's participation in international trade, the influence of this participation on self-sufficiency and the choice of policy on the agricultural sector regulation.

Botkin, Sutygina, and Sutygin (2016) note that the leading world economies maintain a high level of selfsufficiency: the USA and France - 100\%, Germany - 93\%. Since 2014, Russia has been actively pursuing import substitution policy aimed at achieving a high level of food independence. Russia's Food Security Doctrine stipulates the threshold values for food independence indicators for food staples: grain and potato (no less than 95\%); milk and dairy products (no less than 90\%); meat and meat products, salt (no less than 85\%); and sugar, vegetable oil and fish (no less than $80 \%$ ). It is worth mentioning that the approach to assessing self-sufficiency exercised in Russia differs significantly from those employed worldwide.

A number of publications (see, for example, (Kopein, 2016; Pozhidaeva, 2017)) examine food availability and food security from the standpoint of import substitution policy. In particular, Ayapova (2017) highlights that food security is affected by not only the current state of the agricultural market in Russia, but also by the import substitution policy underway that is characterized by an increased level of protectionism, as well as the overall economic situation in the country. Russia's Food Security Doctrine views self-sufficiency as sustainable domestic food production that meets the established threshold values of its specific weight in the commodity resources of the domestic market of the corresponding products (Decree of the RF President, 2010). At the same time, the Doctrine stresses the need to achieve the physical and economic availability of food for every citizen in volumes no less than rational consumption norms. This results in the fact that there are diverse and ambiguous interpretations of the term "food self-sufficiency" (Botkin et al., 2016).

Kuzmin $(2015 ; 2016)$ focuses on defined specifics of a price factors' influence on market balance. The subsequent development of ideas on dynamic security has led to a defined "floating" balance, when the market due to its movement inertia crosses an equilibrium point, from a condition of relative deficit to an account surplus of supply and demand, and vice versa.

Zagashvili (2015) emphasizes the ambiguous interpretation of the concepts of food security, food independence and self-sufficiency. Zagashvili claims that food security is not synonymous with food independence and is ensured by a set of measures that, in addition to the development of domestic food production, involves participation in international trade.

According to the Rosstat method, the level of self-sufficiency is calculated on the basis of the food balance sheet and shows the extent to which a country relies on its own production resources to satisfy the population's need for foods. In general, self-sufficiency ratio (SSR) is defined as:

$$
\mathrm{SSR}=\frac{D P}{D C},
$$

where $D P$ is the volume of domestic production; $D C$ is the volume of domestic consumption.

The level of self-sufficiency can be also calculated on the basis of food supply available for domestic utilization (DS):

$$
\operatorname{SSR}=\frac{D P}{D S}
$$

At that, the volume of food available for consumption, or supply, is calculated as follows (FAO, 2019): (a) supply $=$ production + imports + decrease in stocks; (b) supply $=$ production + imports + changes in stocks $($ decrease or increase); (c) supply = production + imports - exports + changes in stocks (decrease or increase). 


\section{ENTREPRENEURSHIP AND SUSTAINABILITY ISSUES}

ISSN 2345-0282 (online) http://jssidoi.org/jesi/

2020 Volume 7 Number 3 (March)

http://doi.org/10.9770/jesi.2020.7.3(8)

While not denying the significance of international trade for economy, a number of researchers still analyze selfsufficiency in the absence of exports and imports. For instance, Tribushinina and Kurkina (2014) and Pozhidaeva (2011) interpret (regional) food self-sufficiency as an economic situation where a region's food resources are sufficient and there is no need to import foods from other regions. In this case, the level of self-sufficiency is calculated as a ratio of domestic production of foods from a particular category to demand for them (Tribushinina \& Kurkina, 2014; Pozhidaeva, 2011):

$$
S S R=\frac{P}{P C+P C F+F_{L}},
$$

where $P$ denotes production of foods from a particular category per year; $P C$ is productive consumption; $F_{L}$ is loss of foods from a particular category; $P C F$ denotes personal consumption fund.

Mansurov (2017) proposes another way for calculating self-sufficiency, where SSR is defined as a difference between normative food provision based on recommended consumption norms and actual self-sufficiency. The approach suffers from a number of disadvantages, the most significant of which is neglecting imports and exports of foods when evaluating self-sufficiency.

Numerous research studies criticize the existing approaches to assessing food self-sufficiency. Zagashvili (2015) notes that Russia's Food Security Doctrine concentrates solely on manufactured products and does not pay attention to the entire producer-to-consumer supply chain of agri-food products. According to FAO's latest estimates (FAO, 2019a), about 30\% of all food produced globally are lost in the supply chain between the producer and the market. Hence, not all manufactured food is available for consumption, and the issue of reducing food loss along the entire chain of agri-food production has become increasingly urgent (Popova, Vlasov \& Nikitina, 2018; Fomina, Berduygina \& Shatsky, 2018).

Thus, the literature review indicates that, despite the high relevance of sufficiency and availability of foods in Russia, the issues of food self-sufficiency have not yet been adequately investigated and the methodological approaches to assessing its level have a number of drawbacks that distort the real situation.

\section{Methods}

To assess the level of food self-sufficiency, the present study develops an approach based on the following indicators: the level of self-sufficiency adjusted for international trade; the level of self-sufficiency in normative consumption, and the level of self-sufficiency according to the Rosstat method.

\section{Assessing the level of self-sufficiency adjusted for international trade.}

The authors define food self-sufficiency as the level of domestic production in the total volume of food products available for consumption. We use the formula for self-sufficiency ratio that is calculated as a ratio of domestic food production to domestic food consumption (FAO, 2012):

$$
S S R_{C}=\frac{D P}{D P+I-E+\Delta S},
$$

where $D P$ is domestic production; $I$ is imports; $E$ is exports; $\Delta S$ is changes in food stocks.

A high level of losses proves that processing, transportation and storage of foods are inefficient, which directly affects the volume of foods available for domestic consumption. Due to the fact that in Russia food losses in different periods reached up to 13\% (Rosstat, 2019a), the given formula needs to be adjusted for the amount of losses $(L)$ :

$$
S S R_{C}=\frac{(D P-L) \square 00 \%}{D C},
$$


where $D C$ is domestic consumption for production-related and personal goals adjusted for international trade, food losses and changes in stocks calculated by formula:

$$
D C=(D P-L)+I-E+\Delta S
$$

Domestic production, imports, exports and stocks can be measured using the metric system (thousand tonnes, thousand pieces), in monetary terms or in calories. In contrast to the self-sufficiency indicator used in the Rosstat method, this approach demonstrates the share of domestic production not in commodity resources, but in supply of food available for consumption.

Self-sufficiency ratio is calculated for an individual product or product group. FAO does not recommend applying SSR to the overall food situation in a country, since it can disguise the cases where the country is abundant in a certain product, but is forced to import other foods (FAO, 2012).

2. The assessment of self-sufficiency using the Rosstat method takes the following form:

$$
\operatorname{SSR}_{R}=\frac{D P \times 100 \%}{D C_{I}}
$$

where $D C_{I}$ is domestic consumption that combines productive consumption $\left(D C_{P C}\right)$, consumption for personal purposes $\left(D C_{P e r}\right)$, processing for food purposes $\left(D C_{F P}\right)$ and losses $(L)$ :

$$
D C_{I}=D C_{P C}+D C_{P e r}+D C_{F P}+L
$$

Currently, when calculating self-sufficiency, losses are considered as part of domestic consumption, which is correct from the standpoint of production, but not consumers. As follows from the definition, losses are a part of output which is not received by consumers. Following this logic, we exclude losses from the volume of products consumed:

$$
\operatorname{SSR}_{R L}=\frac{(D P-L) \times 100 \%}{D C_{I}} .
$$

The proposed approach eliminates the shortcomings of the Rosstat method for assessing self-sufficiency by the share of domestic production in resources. However, it does not allow for recommended food consumption norms.

\section{Assessing self-sufficiency in normative consumption.}

In addition to the abovementioned indicators, the level of self-sufficiency is evaluated by the share of domestic production in food consumption in accordance with the recommended (rational) norms stipulated by modern requirements for healthy diet (Order of the Ministry of Health, 2016):

$$
S S R_{N}=\frac{(D P-L)}{D C_{n}},
$$

where $D C_{n}$ denotes the consumption level in accordance with rational norms.

In the study, the level of consumption in accordance with rational norms was calculated as the amount of food products available to consumers and adjusted for the degree of rational norms achievement. The latter was determined as a ratio of actual consumption of food staples to rational norms of food consumption. 
Food self-sufficiency is also affected by import diversification. In the current research, the degree of import resource diversification is determined as a diversification index $R_{D}$ that is the reciprocal of the concentration of importers $(y)$ :

$$
R_{D}=\frac{1}{\sum_{i=1}^{k} y_{i}} .
$$

The higher the concentration index, the higher the degree of market monopolization and, consequently, the lower the diversification level of imports, and vice versa.

\section{Results}

Russia is an active participant in international trade and is involved in both food imports and exports. Nevertheless, the Rosstat method for calculating self-sufficiency allows for imports only and does not take into account food exports that reach $30 \%$ and more by certain product groups. For example, since 2013, grain exports have been at the 30 percent level of domestic production. Export of fish and fish products exceeded 50\%, and at some points it reached $60 \%$ (Fig. 1).

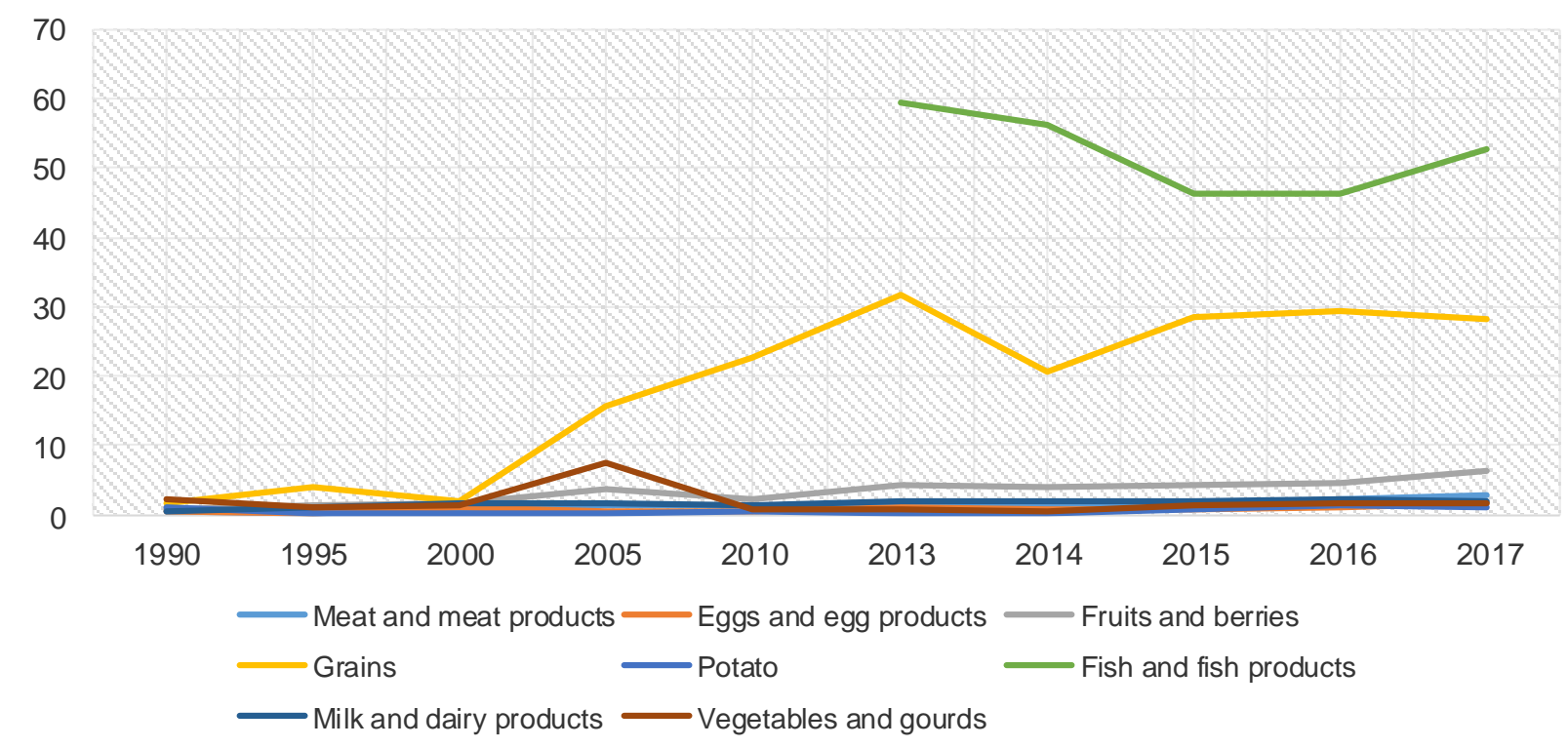

Fig. 1. Share of Russian exports of agricultural products by product groups, $\%$

As follows from the logic of food balance sheets, Rosstat's approach and the method based on normative consumption should deliver the same result with zero net export (which is possible in the absence of international trade or when exports equal imports) and zero losses.

In terms of the given product groups, there is a 40-percent difference in self-sufficiency calculated by the Rosstat method and that developed in the current study. In 2017, according to Rosstat's estimates, self-sufficiency in grains reached $170.65 \%$, whereas a third of the output was exported and not delivered to the national market. According to the proposed method, self-sufficiency in grains in 2017 was $129 \%$. Such a discrepancy in the results is observed throughout the entire period under consideration. For the fish and fish products group, the share of exports exceeds 50\%; however, according to the Rosstat method and the authors' approach, self-sufficiency ratio for different periods varies within 2-20\%, which is due to the large share of imports. In 2013, net exports 


\section{ENTREPRENEURSHIP AND SUSTAINABILITY ISSUES}

ISSN 2345-0282 (online) http://jssidoi.org/jesi/

2020 Volume 7 Number 3 (March)

http://doi.org/10.9770/jesi.2020.7.3(8)

amounted to 381 thousand tonnes of fish and fish products, while exports reached 2694 thousand tonnes (59.57\% of fish catch).

Table 1. Self-sufficiency ratios for food staples

\begin{tabular}{|c|c|c|c|c|c|c|c|c|}
\hline Indicator & 1990 & 2000 & 2010 & 2013 & 2014 & 2015 & 2016 & 2017 \\
\hline \multicolumn{9}{|c|}{ Meat and meat products } \\
\hline $\mathrm{SSR}_{\mathrm{C}}$ & 86.98 & 69.65 & 72.16 & 78.08 & 83.70 & 88.61 & 90.75 & 92.50 \\
\hline $\mathrm{SSR}_{\mathrm{RL}}$ & 87.29 & 66.94 & 72.14 & 78.45 & 82.74 & 88.69 & 90.62 & 93.47 \\
\hline $\mathrm{SSR}_{\mathrm{N}}$ & & & & 79.15 & 84.85 & 88.61 & 91.99 & 95.04 \\
\hline $\mathrm{SSR}_{\mathrm{R}}$ & 88.36 & 67.15 & 72.33 & 78.62 & 82.90 & 88.86 & 90.78 & 93.61 \\
\hline \multicolumn{9}{|c|}{ Grains } \\
\hline $\mathrm{SSR}_{\mathrm{C}}$ & 87.48 & 89.59 & 211.81 & 111.59 & 127.36 & 133.72 & 121.92 & 129.17 \\
\hline $\mathrm{SSR}_{\mathrm{RL}}$ & 91.37 & 102.54 & 93.32 & 141.18 & 154.60 & 149.93 & 161.05 & 172.02 \\
\hline $\mathrm{SSR}_{\mathrm{N}}$ & & & & 137.17 & 156.55 & 162.97 & 148.59 & 157.43 \\
\hline $\mathrm{SSR}_{\mathrm{R}}$ & 91.53 & 102.51 & 93.42 & 140.43 & 153.80 & 149.15 & 160.08 & 170.65 \\
\hline \multicolumn{9}{|c|}{ Milk and dairy products } \\
\hline $\mathrm{SSR}_{\mathrm{C}}$ & 89.51 & 88.65 & 80.33 & 77.29 & 77.56 & 80.63 & 81.55 & 82.76 \\
\hline $\mathrm{SSR}_{\mathrm{RL}}$ & 86.22 & 88.24 & 80.37 & 77.05 & 78.12 & 79.88 & 80.66 & 82.28 \\
\hline $\mathrm{SSR}_{\mathrm{N}}$ & & & & 58.50 & 57.04 & 57.80 & 57.96 & 58.57 \\
\hline $\mathrm{SSR}_{\mathrm{R}}$ & 86.32 & 88.33 & 80.44 & 77.13 & 78.21 & 79.97 & 80.74 & 82.36 \\
\hline \multicolumn{9}{|c|}{ Eggs and egg products } \\
\hline $\mathrm{SSR}_{\mathrm{C}}$ & 97.42 & 97.68 & 98.59 & 98.14 & 98.01 & 97.74 & 97.84 & 98.99 \\
\hline $\mathrm{SSR}_{\mathrm{RL}}$ & 96.92 & 97.50 & 98.32 & 98.00 & 97.59 & 98.16 & 98.60 & 98.86 \\
\hline $\mathrm{SSR}_{\mathrm{N}}$ & & & & 104.18 & 100.65 & 100.75 & 102.73 & 106.23 \\
\hline $\mathrm{SSR}_{\mathrm{R}}$ & 97.24 & 97.59 & 98.57 & 98.21 & 97.76 & 98.36 & 98.77 & 99.10 \\
\hline \multicolumn{9}{|c|}{ Potato } \\
\hline $\mathrm{SSR}_{\mathrm{C}}$ & 99.69 & 96.79 & 136.45 & 97.93 & 93.84 & 91.74 & 101.34 & 99.62 \\
\hline $\mathrm{SSR}_{\mathrm{RL}}$ & 95.43 & 99.54 & 72.10 & 96.21 & 97.90 & 102.19 & 92.77 & 90.53 \\
\hline $\mathrm{SSR}_{\mathrm{N}}$ & & & & 105.55 & 96.97 & 92.76 & 101.34 & 99.62 \\
\hline $\mathrm{SSR}_{\mathrm{R}}$ & 103.32 & 102.66 & 77.02 & 101.44 & 103.22 & 108.29 & 98.96 & 97.06 \\
\hline \multicolumn{9}{|c|}{ Vegetables and gourds } \\
\hline $\mathrm{SSR}_{\mathrm{C}}$ & 83.62 & 82.67 & 83.66 & 84.12 & 82.02 & 84.69 & 87.92 & 84.89 \\
\hline $\mathrm{SSR}_{\mathrm{RL}}$ & 77.00 & 85.19 & 76.28 & 82.54 & 83.64 & 86.38 & 86.99 & 87.20 \\
\hline $\operatorname{SSR}_{N}$ & & & & 61.89 & 59.76 & 61.71 & 64.06 & 63.06 \\
\hline $\mathrm{SSR}_{\mathrm{R}}$ & 82.21 & 88.20 & 78.79 & 85.58 & 86.56 & 89.42 & 90.04 & 90.19 \\
\hline \multicolumn{9}{|c|}{ Fruits and berries } \\
\hline $\mathrm{SSR}_{\mathrm{C}}$ & 52.50 & 50.74 & 25.25 & 29.95 & 34.58 & 33.65 & 35.94 & 33.33 \\
\hline $\mathrm{SSR}_{\mathrm{RL}}$ & 49.20 & 55.26 & 26.01 & 31.05 & 31.75 & 31.74 & 35.92 & 32.40 \\
\hline $\mathrm{SSR}_{\mathrm{N}}$ & & & & 17.97 & 21.79 & 20.19 & 21.57 & 19.66 \\
\hline $\mathrm{SSR}_{\mathrm{R}}$ & 57.13 & 56.33 & 27.05 & 32.08 & 32.83 & 32.81 & 36.88 & 33.40 \\
\hline \multicolumn{9}{|c|}{ Fish and fish products } \\
\hline $\mathrm{SSR}_{\mathrm{C}}$ & - & - & - & 116.70 & 111.30 & 127.21 & 125.46 & 146.77 \\
\hline $\mathrm{SSR}_{\mathrm{RL}}$ & - & - & - & 112.66 & 115.22 & 133.14 & 141.13 & 139.05 \\
\hline $\operatorname{SSR}_{N}$ & - & - & - & 115.11 & 112.82 & 122.01 & 122.61 & 143.44 \\
\hline $\mathrm{SSR}_{\mathrm{R}}$ & - & - & - & 113.56 & 116.17 & 134.28 & 142.37 & 140.10 \\
\hline
\end{tabular}

Source: calculated using the data of Rosstat 2019.

The agricultural sector in Russia experiences quite significant losses in certain food groups. For example, in 1990, losses in the product group "Fruits and berries" reached 14\% (Fig. 2). By 2013, they were reduced to 3\%. As for 
the product group "Vegetables and gourds", in 1990, losses were over 6\%; by 2013, the level was lowered to $3.5 \%$. Losses in potato not only remain at the highest level, but also continue increasing. The minimum loss in potato was witnessed in 2000 (3.03\%); by 2017, it increased to 6.73\%. Significant losses in the Russian crop production are due to a lack of modern high-tech storage facilities, poorly developed infrastructure, and a vast territory, which increases the time of transportation of perishable products from the manufacturer to the final consumer.

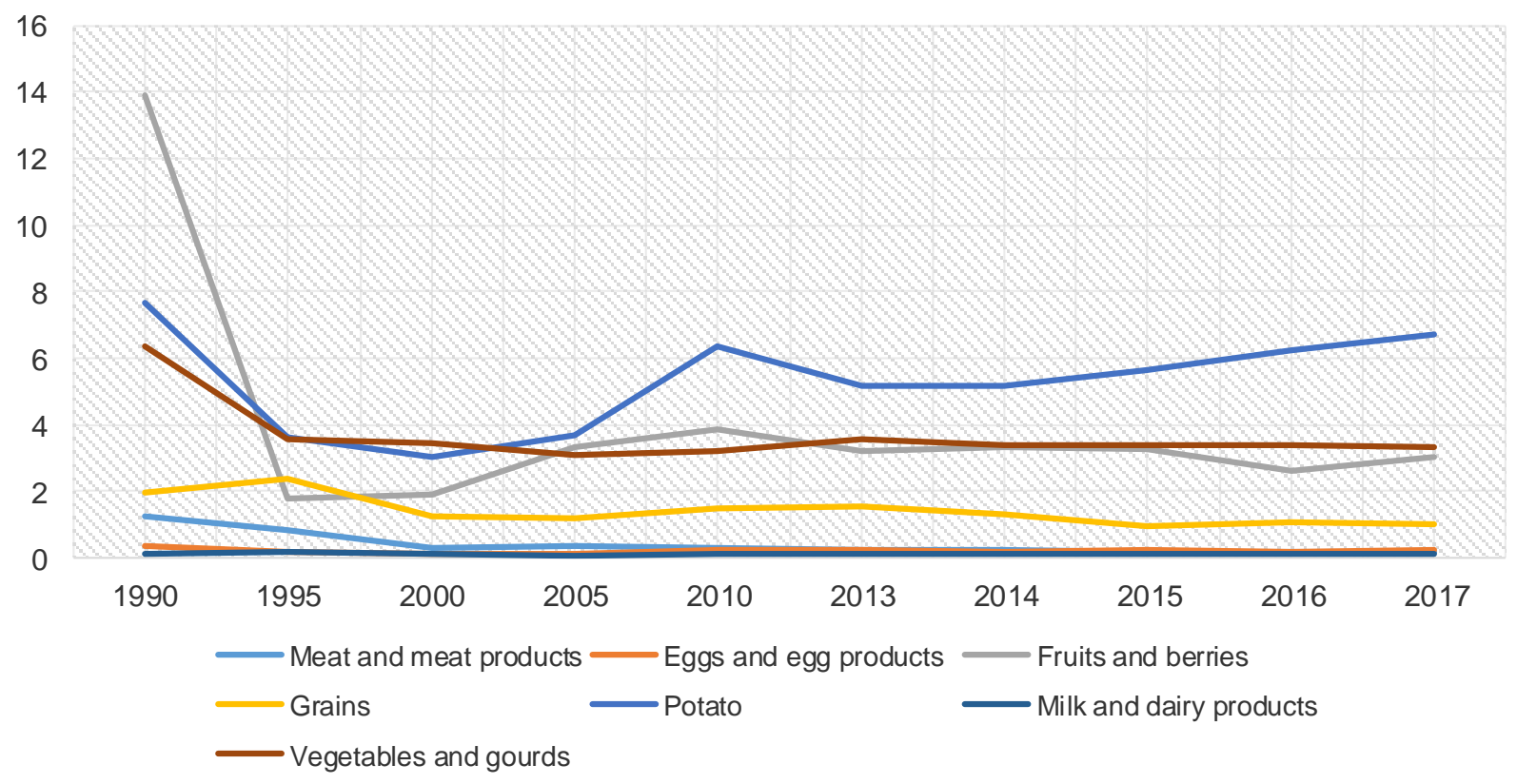

Fig. 2. Losses in agricultural products, $\%$

Source: calculated using the data of Rosstat 2019.

Serious losses exert a marked effect on self-sufficiency. In 1995, self-sufficiency in fruits and berries, with a loss level of about $14 \%$, calculated according to the Rosstat method was $57.13 \%$, and according to the method adjusted for the loss rate $-49.2 \%$.

Self-sufficiency ratio determined by the authors' method showed that self-sufficiency of some product groups started growing prior to the active implementation of the import substitution policy. For example, self-sufficiency in grains was increasing throughout the entire period under study; since 2005, there has been an increase in selfsufficiency in meat and meat products. Self-sufficiency in milk/dairy products and fruits/berries was falling from the beginning of the 1990s to the mid-2000s. Russia has not yet managed to reach the self-sufficiency level of the 1990s. Self-sufficiency in eggs and egg products remained at a high level throughout the entire period under examination; an insignificant rise in the product group "Vegetables and gourds" occurred in 2012.

Nevertheless, when comparing food self-sufficiency in 2013 and 2017, we can note a substantial rise in selfsufficiency in grains, fish and fish products; a moderate growth in meat and meat products; an insignificant increase in milk and dairy products, vegetables and gourds, eggs and egg products; and a decline in selfsufficiency in potato and fruits and berries.

The primary target indicator of Russia's Food Security Doctrine is the level of achievement of rational norms of food consumption per capita (Table 2). 
Table 2. Level of achievement of rational norms of food consumption

\begin{tabular}{|c|c|c|c|c|c|c|c|}
\hline \multirow[t]{2}{*}{ Food group } & \multirow{2}{*}{$\begin{array}{c}\text { Rational norms, } \\
\mathrm{kg} / \text { year/person }\end{array}$} & \multicolumn{6}{|c|}{$\begin{array}{c}\text { Actual consumption / } \\
\text { Level of achievement of rational norms }\end{array}$} \\
\hline & & 2012 & 2013 & 2014 & 2015 & 2016 & 2017 \\
\hline \multirow[t]{2}{*}{ Meat and meat products in terms of meat } & \multirow[t]{2}{*}{73} & 74 & 75 & 74 & 73 & 74 & 75 \\
\hline & & - & 1.01 & 1.01 & 1.00 & 1.01 & 1.03 \\
\hline \multirow[t]{2}{*}{ Milk and dairy products in terms of milk } & \multirow[t]{2}{*}{325} & 246 & 245 & 239 & 233 & 231 & 230 \\
\hline & & - & 0.76 & 0.74 & 0.72 & 0.71 & 0.71 \\
\hline \multirow[t]{2}{*}{ Eggs and egg products, pieces } & \multirow[t]{2}{*}{260} & 276 & 270 & 267 & 268 & 273 & 279 \\
\hline & & - & 1.06 & 1.03 & 1.03 & 1.05 & 1.07 \\
\hline \multirow[t]{2}{*}{ Potato } & \multirow[t]{2}{*}{90} & 97 & 94 & 93 & 91 & 90 & 90 \\
\hline & & - & 1.08 & 1.03 & 1.01 & 1.00 & 1.00 \\
\hline \multirow[t]{2}{*}{ Vegetables and gourds } & \multirow[t]{2}{*}{140} & 103 & 102 & 102 & 102 & 102 & 104 \\
\hline & & - & 0.74 & 0.73 & 0.73 & 0.73 & 0.74 \\
\hline \multirow[t]{2}{*}{ Fruits and berries } & \multirow[t]{2}{*}{100} & 60 & 63 & 63 & 60 & 60 & 59 \\
\hline & & - & 0.60 & 0.63 & 0.60 & 0.60 & 0.59 \\
\hline \multirow[t]{2}{*}{ Bread products } & \multirow[t]{2}{*}{96} & 118 & 118 & 118 & 117 & 117 & 117 \\
\hline & & - & 1.23 & 1.23 & 1.22 & 1.22 & 1.22 \\
\hline \multirow[t]{2}{*}{ Fish products } & \multirow[t]{2}{*}{22} & 21.7 & 22.3 & 22.3 & 21.1 & 21.5 & 21.5 \\
\hline & & - & 0.99 & 1.01 & 0.96 & 0.98 & 0.98 \\
\hline
\end{tabular}

Source: calculated using the data of Rosstat 2019b; Order of the Ministry of Health..., 2016).

Changes in the consumption indicators show that, after a fall in the quality of nourishment in 2014 and 2015, consumption increased and neared the recommended norms, excluding fruits, vegetables and dairy products. In this regard, consumption of bread and alimentary paste is significantly higher than the recommended norms. At that, the nutritional value of the existing diet is also not satisfactory (Table 3).

Table 3. Nutritional value of the existing diet, gram per day/family member

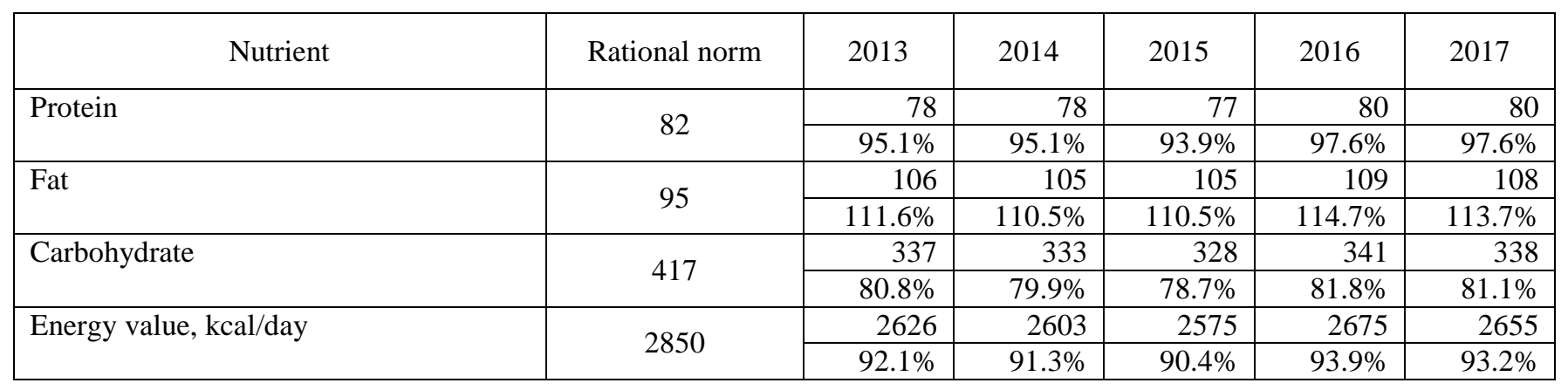

Source: calculated using the data of Rosstat 2019b; Order of the Ministry of Health..., 2016).

As shown in Table 3, fat intake exceeds the recommended norm, while carbohydrate and protein intake are $2 \%$ and $19 \%$ lower than the norms, respectively. In addition, the grocery basket is still low in calories.

Another negative factor restricting the availability of foodstuffs of some product groups is a decrease in import diversification. The degree of diversification calculated for 4 and 20 largest importers demonstrated a fall in diversification (Table 4). 
ENTREPRENEURSHIP AND SUSTAINABILITY ISSUES

ISSN 2345-0282 (online) http://jssidoi.org/jesi/

2020 Volume 7 Number 3 (March)

http://doi.org/10.9770/jesi.2020.7.3(8)

Table 4. Changes in diversification of food imports

\begin{tabular}{|c|c|c|}
\hline Product group & 2013 & 2018 \\
\hline \multicolumn{3}{|c|}{ Products of animal origin } \\
\hline Degree of diversification $\mathrm{R}_{\mathrm{D} 4}$ & 2,3753 & 1,6181 \\
\hline Degree of diversification $R_{D 20}$ & 1,1455 & 1,0881 \\
\hline \multicolumn{3}{|c|}{ Vegetable products } \\
\hline Degree of diversification $R_{D 4}$ & 3,1447 & 2,9586 \\
\hline Degree of diversification $R_{D 20}$ & 1,3514 & 1,2788 \\
\hline \multicolumn{3}{|c|}{ Foods, drinks, tobacco } \\
\hline Degree of diversification $\mathrm{R}_{\mathrm{D} 4}$ & 3,2362 & 3,0960 \\
\hline Degree of diversification $R_{D 20}$ & 1,3351 & 1,3387 \\
\hline
\end{tabular}

Source: calculated using the data of Federal Customs Service 2019.

The greatest fall in import diversification in 2018 in comparison with 2013 occurred in products of animal origin (by 0.7572 ), almost $40 \%$ of which were imported from the Republic of Belarus.

Thus, the calculation of food self-sufficiency in Russia by the share of domestic food resources production (the Rosstat method) proves that the country's self-sufficiency level is rather high. As a result, a number of experts (Shagayda et al., 2018) suppose that the objective of the import substitution policy is accomplished and the country is food independent.

To sum up, Russia is self-sufficient in fish products and grains, while there is an excessive intake of bread and alimentary paste if compared with the recommended norms. Self-sufficiency in dairy products, vegetables and fruits is low, which makes these products quite expensive and, thus, inaccessible for many households, even considering their integral role in healthy diet. If the consumption of some foods is below the level of the established norms and above the rational consumption norms of other cheaper foods, it has a negative effect on the population's health (Pozhidaeva, 2017).

\section{Discussion}

Economic and physical availability of foodstuffs is of crucial importance for Russia with its significant social differentiation in terms of food consumption and personal income. A number of researchers (Zhiryaeva, 2017) report that spending on food is growing. In 2017, households in Russia spent more than 36\% of their total consumption expenditure on food, whereas for households in the European Union this share amounted to $12.2 \%$ (Eurostat, 2019). At the same time, the number of minimum grocery baskets reduced from 9.2 in 2013 to 8.15 in 2017. The actual consumption of some foods in Russia lags far behind similar indicators of developed countries. For example, consumption of meat and meat products in Russia is $72.6 \mathrm{~kg}$, in the EU countries $-82 \mathrm{~kg}$, the United States - $110 \mathrm{~kg}$ (Shakleina, Shvetsova, \& Shaklein, 2018). In comparison with Belarus, Russian meat consumption is $16 \mathrm{~kg}$ less, milk and dairy products $-15 \mathrm{~kg}$, eggs $-15 \mathrm{pcs}$, potato $-58 \mathrm{~kg}$, vegetables and gourds $34 \mathrm{~kg}$, fruits and berries $-18 \mathrm{~kg}$. At the same time, Russian consumption of bread and alimentary paste is $32 \mathrm{~kg}$ more (Chernova, 2018).

A decrease in import diversification, in addition to the risk of short food supply in the event of crop failure or due to other factors, carries the risk of deterioration in the quality of imported products. In 2013, the Netherlands (9.5\%), Poland (8.6\%), Israel $(8.3 \%)$ and Spain $(8.3 \%)$ were the main food importers to the Russian Federation with 100-percent food safety indicator. The share of Turkey in the Russian market for imported foods was $19.8 \%$ with food safety indicator of $99.2 \%$. China accounted for only $13.4 \%$ of imports with food safety indicator of 


\section{ENTREPRENEURSHIP AND SUSTAINABILITY ISSUES}

ISSN 2345-0282 (online) http://jssidoi.org/jesi/

2020 Volume 7 Number 3 (March)

http://doi.org/10.9770/jesi.2020.7.3(8)

97.1\%. In 2018, nearly a quarter of vegetable imports came from China (22.6\%), followed by Azerbaijan (12.5\%), Egypt (10.9\%) and Belarus (10.6\%) with food safety indicator of 89\%, 98.8\% and 98.6\%, respectively (Global Food Security Index, 2018).

The similar situation is typical of the market for imported meat and meat products, where the share of countries with 100-percent food safety indicator (Germany, Denmark) was reduced in favor of suppliers of lower quality foods (Belarus). In 2018, Belarus held a monopolistic position in the Russian market for dairy products increasing its share to $74.3 \%$. Food safety indicator of the Russian products (97.5\%), imports of which were significantly reduced in order to stimulate their domestic production, was also well below the level of developed countries.

Thus, we can argue that Russia's Food Security Doctrine is being implemented without taking into account how it contributes to meeting the population's needs for food. Despite the fact that the term "food security" is based on international practice, there is a conflict between various aspects of the understanding of this term. The reason behind the conflict lies in the interpretation and assessment of food self-sufficiency. Currently, the Doctrine is focused on production, but not consumer. When discussing food security, the first place is given to the growth of domestic production of the required amount of food, rather than ensuring the physical and economic availability of foods for the population (Trotsuk, Nikulin, \& Wegren, 2018). At that, food self-sufficiency is calculated according to the resources available, but not to the amount of food delivered for domestic consumption. A rise in food independence through growing domestic production and reducing imports cannot guarantee that the population's needs for high quality food will be satisfied in the amount adequate to the recommended norms.

This discrepancy makes it necessary to clarify the purposes and objectives of the Doctrine and undertake an extensive revision of the list of the core assessment indicators of food security. It is reasonable to expand the list of the Doctrine's performance indicators by including the following ones: the level of self-sufficiency in supply taking into account international trade; the level of self-sufficiency in normative consumption; and the degree of import diversification.

\section{Conclusion}

The choice of a national food security strategy depends on the production resources available as well as the level of economic, political and social atmosphere in a country. Russia's Food Security Doctrine stipulates the threshold values of indicators and a methodology for assessing food independence for food staples. There are significant differences in the approaches exercised in Russia and other countries to evaluating the self-sufficiency level. The research results revealed a 40-percent difference in self-sufficiency levels calculated using the Rosstat method and that proposed in the paper. The calculated self-sufficiency ratio showed that for some product groups self-sufficiency started growing prior to the active implementation of the import substitution policy. The revealed contradiction makes it necessary to revise the list of key indicators for assessing food security. Food selfsufficiency calculated using the proposed method indicated that Russia was self-sufficient in only three food groups, while self-sufficiency in other groups was extremely low. The study also demonstrated a decline in the degree of import diversification, which might entail the risk of short food supply in the event of crop failure or due to other factors. The research found that the domestic production of grains exceeded the rational consumption norms, which resulted in the excessive consumption of this type of food if compared to the recommended standards. At the same time, self-sufficiency in dairy products and vegetables was low and self-sufficiency in fruits was extremely low. 


\section{ENTREPRENEURSHIP AND SUSTAINABILITY ISSUES}

ISSN 2345-0282 (online) http://jssidoi.org/jesi/

2020 Volume 7 Number 3 (March)

http://doi.org/10.9770/jesi.2020.7.3(8)

\section{Acknowledgments}

The reported study was funded by RFBR (Russian Foundation for Basic Research), "Intensification of militaryeconomic cooperation in the space of the Collective Security Treaty Organization and the Eurasian Economic Union in the context of the sanctions policy of developed countries and the development of import substitution in the Russian Federation", project № 18-010-01132.

\section{References}

Ayapova, Zh. M. (2017). Indicators and criteria for assessing the state of food security: The experience of Kazakhstan and foreign countries. Proceedings of the Voronezh State University of Engineering Technologies, 1(71), 445-450. https://doi.org/10.20914/2310$\underline{1202-2017-1-445-450}$

Baer-Nawrocka, A., \& Sadowski, A. (2019). Food security and food self-sufficiency around the world: A typology of countries. PLoS ONE, 14(3), e0213448. https://doi.org/10.1371/journal.pone.0213448

Botkin, O. I., Sutygina, A. I., \& Sutygin, P. F. (2016). National issues of food security assessment. Bulletin of Udmurt University. Series: Economics and Law, 26(4), 20-27.

Chernova, V. Yu. (2018). Development of import substitution strategy in Russia (the case study of agribusiness). Moscow: Triumf.

Clapp, J. (2017). Food self-sufficiency: Making sense of it, and when it makes sense. Food Policy, 66, 88-96. https://doi.org/10.1016/j.foodpol.2016.12.001

Decree of the RF President of January 30, 2010 no. 120 "On Approving the Doctrine of Food Security of the Russian Federation".

Ecker, O., Breisinger, C. (2012). The food security system. A new conceptual framework. IFPRI Discussion Paper 01166. Retrieved from https://www.researchgate.net/publication/254416916_The_Food_Security_System_A_New_Conceptual_Framework

Eurostat. (2019). How much are households spending on food? Retrieved from https://ec.europa.eu/eurostat/web/products-eurostat-news/$\underline{\text { DDN-20181204-1 }}$

FAO. (1999). Implications of Economic Policy for Food Security: A Training Manual. Retrieved from http://www.fao.org/3/x3936e/X3936E00.htm

FAO. (2001). The State of Food Insecurity in the World 2001. FAO, Rome 2002. Retrieved from http://www.fao.org/3/a-y1500e.pdf

FAO. (2012). FAO Statistical Yearbook 2012 - World Food and Agriculture. Retrieved from http://www.fao.org/3/i2490e/i2490e00.htm

FAO. (2019). Suite of Food Security Indicators. Retrieved from http://www.fao.org/faostat/en/\#data/FS

FAO. (2019a). Food Loss and Food Waste. Retrieved from http://www.fao.org/food-loss-and-foodwaste/en/?amp $\% 3$ Butm_medium=social $\% 20$ media\&amp\%3Butm_campaign=faoknowledge

Federal Customs Service 2019. Retrieved from http://www.customs.ru/

Financial Times. (2009). Feast and Famine: Aim of Self-Sufficiency Would be Disastrous Globally. Anonymous Editorial, August 10.

Fomina, A. V., Berduygina, O. N., \& Shatsky, A. A. (2018). Industrial cooperation and its influence on sustainable economic growth. Entrepreneurship and Sustainability Issues, 5(3), 467-479. https://doi.org/10.9770/jesi.2018.5.3(4) 


\section{ENTREPRENEURSHIP AND SUSTAINABILITY ISSUES}

ISSN 2345-0282 (online) http://jssidoi.org/jesi/

2020 Volume 7 Number 3 (March)

http://doi.org/10.9770/jesi.2020.7.3(8)

Global Food Security Index. (2018). Retrieved from https://foodsecurityindex.eiu.com/Country.

Kopein, V. V. (2016). Economic and food security: New reality of import substitution. Food Processing: Techniques and Technology, $40(1), 126-134$.

Kuzmin, E. A. (2015). Food security modelling. Biosciences Biotechnology Research Asia, 12 (Spl. Edn. 2), $773-781$. https://doi.org/10.13005/bbra/2259

Kuzmin, E. A. (2016). Sustainable food security: floating balance of markets. International Journal of Economics and Financial Issues, 6(1), 37-44.

Mansurov, R. E. (2017). A system for assessing the region's self-sufficiency in basic food products as an element of regional management of the agroindustrial complex (a case study of the Smolensk region). Economics, Taxes \& Law, 4, 107-113.

Moumen, Z., El Idrissi, N.E.A., Tvaronavičienè, M., Lahrach, A. (2019). Water security and sustainable development. Insights into Regional Development, 1(4), 301-317. https://doi.org/10.9770/ird.2019.1.4(2)

Order of the Ministry of Health and Social Development of the Russian Federation of August 19, 2016 no. 614 "On the approval of recommendations on rational food consumption standards that meet modern requirements for a healthy diet".

Popova, I. N., Vlasov, A. I., \& Nikitina, N. I. (2018). Optimization of inventory distribution logistics in industrial enterprises. Espacios, 39(24), Art. no 16.

Pozhidaeva, E. S. (2011). Assessment of the level of self-sufficiency in meat and meat products of the population of the Russian Federation. Economic Analysis: Theory and Practice, 10(46), 27-31.

Pozhidaeva, E. S. (2017). Economic and statistical analysis of food staples consumption under foreign trade restrictions. Economic Analysis: Theory and Practice, 16(1), 116-127. https://doi.org/10.24891/ea.16.1.116

Rosstat (2019a). Official statistics. Retrieved from http://www.gks.ru/

Rosstat (2019b). Agriculture bulletins $\quad$ (electronic $\quad$ versions). $\quad$ Retrieved http://www.gks.ru/wps/wcm/connect/rosstat_main/rosstat/ru/statistics/publications/catalog/doc_1265196018516

Shagayda, N. I., Nikulin, A. M., Uzun, V. Ya., Trotsuk, I. V., \& Shishkina, E. A. (2018). Monitoring the state of food security in Russia in 2014-2016. Moscow: Delo.

Shakleina, M. V., Shvetsova, K. D., \& Shaklein, K. I. (2018). Assessment of the impact of sanctions on the market of meat and meat products in Russia: Current state and prospects for market development. Problems of Territory's Development, 1(93), 57-70. https://doi.org/10.15838/ptd/2018.2.93.4

Todorov, G. N., Barbakov, O. M., Nikitina, N. I., \& Chernova, V. Y. (2018). Specifics in modelling of energy efficient production in agribusiness. International Journal of Energy Economics and Policy, 8(3), 51-57.

Tribushinina, O. S., \& Kurkina, N. R. (2014). Assessment of level of food self-sufficiency of the region. Fundamental Research, 6(5), $1023-1027$.

Trotsuk, I. V., Nikulin, A. M., \& Wegren, S. (2018). Interpretations and dimensions of food security in contemporary Russia: Discursive and real contradictions. Universe of Russia, 27(1), 34-64. https://doi.org/10.17323/1811-038X-2018-27-1-34-64.

Zagashvili, V. S. (2015). Food security of Russia in the conditions of deterioration of the relations with the EU. Russian Foreign Economic Journal, 8, 46-59.

Zhiryaeva, E. V. (2017). Food caught in the sanctions was: Is food security a casualty? Administrative Consulting, 9, 117-133. https://doi.org/10.22394/1726-1139-2017-9-117-133 


\section{ENTREPRENEURSHIP AND SUSTAINABILITY ISSUES}

ISSN 2345-0282 (online) http://jssidoi.org/jesi/

2020 Volume 7 Number 3 (March)

http://doi.org/10.9770/jesi.2020.7.3(8)

Veronika Yu. CHERNOVA, Associate Professor, Cand. Sci. (Economic), People's Friendships University of Russia, Department of Marketing; Institute of Marketing, State University of Management. Professional interests: world economy, marketing of transnational companies, importsubstitution, product personalization, one-to-one marketing, interactive marketing communications. Recent articles are published in a cooperation with research colleaques in a field of retailer's communication strategies; product personalization, managing data-driven advertising campaigns.

ORCID ID: orcid.org/0000-0001-5951-9091

Alexander M. ZOBOV, Professor, Cand. Sci. (Economic), People's Friendships University of Russia, Head of the Department of Marketing. Professional interests: cooperation with BRICs countries, international marketing strategies, strategic marketing, world economy, marketing of transnational companies, importsubstitution, product personalization, one-to-one marketing, interactive marketing communications. Recent articles are published in a cooperation with research colleaques in a field of retailer's communication strategies; product personalization, managing data-driven advertising campaigns.

ORCID ID: orcid.org/0000-0002-8792-1990

Ekaterina A. DEGTEREVA, Associate Professor, Cand. Sci. (Economic), People's Friendships University of Russia, Department of Marketing. Professional interests: world economy, marketing of transnational companies, importsubstitution, product personalization, oneto-one marketing, interactive marketing communications. Recent articles are published in a cooperation with research colleaques in a field of retailer's communication strategies; product personalization, managing data-driven advertising campaigns.

ORCID ID: orcid.org/0000-0002-8752-5840

Vasily S. STAROSTIN, Associate Professor, Cand. Sci. (Economic), Head of Advertising and PR Department, Institute of Marketing, State University of Management. Professional interests: product personalization, one-to-one marketing, interactive marketing communications. Recent articles are published in a cooperation with research colleaques in a field of retailer's communication strategies; product personalization, managing data-driven advertising campaigns.

ORCID ID: orcid.org/0000-0003-2243-7345

Inna V. ANDRONOVA, Professor, Dr. Sci. (Economic), Department of international economic relations, Peoples' Friendship University of Russia. Professional interests: world economy, import substitution, balance of exports and imports, economic security, interactive marketing communications, multinational corporations, marketing of transnational companies, balance of resources, food security risks, monetary policy.

ORCID ID: orcid.org/0000-0003-1940-6978

Register for an ORCID ID:

https://orcid.org/register

Copyright (C) 2020 by author(s) and VsI Entrepreneurship and Sustainability Center

This work is licensed under the Creative Commons Attribution International License (CC BY).

http://creativecommons.org/licenses/by/4.0/

(c) (i) Open Access 